\author{
Ю. Ю. Гордова \\ Институт языкознания РАН \\ Москва, Россия \\ onyma-ryazan@yandex.ru
}

\title{
Приемы и методы ономастической реконструкции: восстановление топонимии предыдущего хронологического слоя по названиям пустошей, городищ, селищ (на материале рязанской средневековой топонимии)
}

Сведения памятников письменности по топонимии большинства периферийных русских регионов вплоть до XVI в. крайне скудны. Они дают в руки исследователя лишь отдельные, во многом фрагментарные факты, не позволяющие рассматривать топонимию раннего периода как систему. В такой ситуации возникает необходимость поиска новых приемов и методов, позволяющих выявлять названия, которые по своим формальным, семантическим и иным признакам могут быть отнесены к топонимии древнерусского времени. Одним из них может служить прием восстановления ранних названий региона по названиям пустошей, городищ и селищ, упоминаемых в средневековых документах. Источники этого времени носят уже массовый характер и содержат богатый материал, который может быть использован и для реконструкции названий предыдущего хронологического слоя. Прием рассматривается на материале рязанской топонимии.

В ходе ономастической выборки из текстов древнерусских летописей удалось выявить 66 наименований, относящихся к территории Рязанского великого княжества (образовано в середине XII в.). В их числе древнейший русский ойконим этой земли, название стольного города Рязань. История топонима необычна. Город впервые упоминается в летописях под 1095 г., в 1237 г. столица княжества была почти полностью уничтожена войсками хана Батыя. Однако ликвидация города привела не к переходу его названия в разряд исторических, а к тому, что имя утраченного объекта стало наименованием всей Рязанской земли. Постепенно наметилась тенденция переноса топонима

(С Гордова Ю. Ю., 2019 
на другое поселение, выполнявшее функции столицы и имевшее собственное название - Переяславль. Процесс проходил в течение XIV в.

История названия Рязань служит яркой иллюстрацией древнейшей топонимической традиции сохранения особо значимых топонимов после утраты самого объекта, носителя имени. Однако эта особенность древнерусской топонимии распространяется не только на названия важнейших городов области, но и на названия рядовых поселений. В случае утраты поселения его имя переходило на близлежащие объекты (водоемы, поля, другие поселения) или сохранялось в качестве названия городища, селища или пустоши, оставшихся на заброшенном месте. Впоследствии здесь вновь могло возникнуть поселение, и ему давали имя исчезнувшего города или села. Благодаря этому оним мог сохраняться в течение нескольких столетий.

Это подтверждает история отдельных топонимов, которые точно локализованы и соотнесенность которых с объектами не вызывает сомнений. В частности, место уничтоженного летописного города Перевитска уже в источниках XVI в. называется Перевичким Городищем [ПК, 165], рядом с ним - Перевицкая чернопосаикая земля, Перевицкий посад, или Перевитикк на посаде [Там же, 165, 175, 178]; позднее в том же районе возникает деревня Перевицкий Торжок.

B XIV в. в районе р. Глинка существовала деревня, название которой фиксируется только в XVI в. как название «пустоши, что была д. Митякино» [ПК, 214]. Существующая здесь в наши дни деревня тоже носит название Митякино [АКР, 3, 43; Гордова, 2010, 51], т. е. на месте пустоши вновь возникло поселение, перенявшее историческое имя.

Полагаем, что появление географических терминов городище, городец, городок, селище, пустошь также было вызвано желанием сохранить память об утраченных поселениях, что и отражено в семантике лексем: городище 'место, где раньше был город', городеи, городок 'место, где раньше было небольшое укрепленное поселение', селище 'место, где раньше было сельское поселение', пустошь 'запустевшее место'.

При образовании топонимов эти термины использовались как самостоятельно, без дополнительных лексических и морфологических средств (д. Городище, д. Селище), так и в составе двучленных или трехчленных наименований с участием определений, указывающих на имя старого поселения. Такие топонимы (Глебово Городище, Селинское Городище; Горбиово Селище, Ивановское Пронино Селище, Литвиновское 
Селище, Селище Романовское Побежимова и т. д.) позволяют восстановить названия древних поселений: г. Глебов, г. Сель / Селинск, д. Горбияова, д. Ивана Пронина, д. Литвинова, д. Романа Побежсиова и т. д.

Ряд топонимов проходит «трехступенчатую» транстопонимизацию, сначала сохраняясь в названии селища, затем в названии деревни - уже в составном образовании с участием поселищного термина, и далее в названии пустоши, которое, как правило, передается в средневековых записях при помощи конструкций типа «в пустоши, что была д. Княжное Селище». Эти сведения представляются весьма ценными в свете задач реконструкции ономастической картины региона в условиях малочисленности письменных свидетельств.

АКР - Краснов Ю. А., Михальченко С. Е. Археологическая карта России: Рязанская область : в 3 ч. М., 1993-1996.

Гордова Ю. Ю. Топонимия Рязанской области (список географических названий). Ч. 1 : Современная топонимия. Вып. 1 : Территория бассейна реки Прони. Рязань, 2010.

ПК - Писцовые книги Рязанского края XVI в. / ред. В. Н. Сторожев. 2-е изд. Т. 1. Вып. 1. Рязань, 1996.

DOI 10.31168/7996-2700-3.35

\section{С. О. Горяев*, Ю. А. Кривощапова**}

Уральский федеральный университет

Екатеринбург, Россия

*gorajev@yandex.ru

**insekt@yandex.ru

\section{Этикетное слово как маркер онимизации и трансонимизации*}

В докладе речь идет о процессах образования новых имен в периферийной сфере ономастического пространства - эргонимии. Об онимизации и трансонимизации как способах образования рекламных имен, в том числе эргонимов, пишет, в частности,

\footnotetext{
* Исследование проводится при поддержке гранта РФФИ № 18-012-00586 «Урбанонимы как часть языкового ландшафта города: традиции и перспективы рационального развития».

(C) Горяев С. О., Кривощапова Ю. А., 2019
} 